\section{Radhwan H Hasan}

BDS, MSc (Lectu)

\title{
The Effect of Microwave Disinfection on Tensile Strength of Dental Gypsum
}

\author{
Department of Prosthetic Dentistry \\ College of Dentistry, University of Mosul
}

\begin{abstract}
Aims: To evaluate the effect of microwave disinfection on diametral tensile strength (DTS) of type III and type IV dental stones. Materials and Methods: A total of 80 cylindrical specimens was prepared with dimensions $40 \mathrm{~mm}$ in height and $20 \mathrm{~mm}$ in diameter. These specimens were divided into 4 main groups: Geastone type III, Zeta type III, Micromod type IV and Silky Rock type IV. Twenty specimens for each main group were divided into 10 specimens as control subgroup and 10 specimens representing microwave irradiated subgroup. The microwave irradiation was performed in a household microwave oven at 900 watts for 5 minutes. The DTS was conducted on a mechanical testing machine at a cross head speed of $1.0 \mathrm{~mm} /$ minute. The data were statistically analyzed using Student's t-test, analysis of variance and Duncan's Multiple Range test. Results: The microwave disinfection caused significant increase in DTS $(p \leq 0.05)$ for all types of dental stone, and dental stones type IV (Micromod and Silky Rock) had significantly higher DTS ( $p \leq 0.05$ ) than dental stones type III (Geastone and Zeta)._Conclusion: Microwave disinfection of gypsum cast cause significantly increase in diametral tensile strength of type III and type IV dental stone.

Key Words: Microwave disinfection, diametral tensile strength, stone, dental gypsum.
\end{abstract}

Hasan HR. The Effect of Microwave Disinfection on Tensile Strength of Dental Gypsum. Al-Rafidain Dent J. 2008; 8(2):213-218.

Received: $1 / 8 / 2007$

Sent to Referees: $1 / 8 / 2007$

Accepted for Publication: 12/11/2007

\section{INTRODUCTION}

Studies demonstrated that the usual operating procedures of the prosthodontic laboratory are a possible source of crosscontamination between patients, technicians and dental personnel ${ }^{(1-4)}$, and the potential sources of transmission of infectious diseases from patients to dental technicians include impressions, impression trays and gypsum casts ${ }^{(5)}$.

As impression disinfection is difficult and associated with several problems, attention was directed towards cast disinfection $^{(6)}$.

Several methods have been recommended to disinfect dental casts, which include spraying the casts with disinfecting solution ${ }^{(7)}$, using die stone containing disinfectant ${ }^{(8)}$, immersing the casts in disinfecting solution, ${ }^{(9-11)}$ or incorporating chemicals into gypsum at the time of mixing $^{(12-14)}$.

Studies showed that these methods may affect the physical and mechanical properties of dental stone, such as setting time, compressive strength and dimen- sional accuracy ${ }^{(12-16)}$. Microwave energy has been suggested for disinfection of gypsum casts, but the effect of microwave energy on gypsum material has not been thoroughly examined.

Therefore, the purposes of this study was to investigate the diametral tensile strength (DTS) of types IV and III dental stones disinfected by microwave technique.

\section{MATERIALS AND METHODS}

In this study, 4 types of dental stones were evaluated. These stones and the water/powder ratios recommended by their manufacturers were listed in Table (1).

Split metal mold was used to construct stone cylindrical specimens with dimensions $40 \mathrm{~mm}$ in height and $20 \mathrm{~mm}$ in diameter according to ADA Specification No. $25^{(17)}$.

The recommended powder was added to the water in a rubber bowl and mixed by hand to a smooth consistency. Mixed dental stones were poured down the side of 
the inclined mold retained on a glass plate, the mold was vibrated using vibrator (BEGO, Germany) during filling to draw out air bubbles from the mixture and reduce porosity.

Table (1): The tested dental stones and their powder/liquid ratio

\begin{tabular}{ccccc}
\hline Product & Type & $\begin{array}{c}\text { Powder/water Ratio } \\
\text { (gm/mL) }\end{array}$ & Batch No. & Manufacturer \\
\hline Micromod & IV & $100 / 23$ & 599030605 & $\begin{array}{c}\text { Zeus Seri Loc. Tamburino } \\
\text { 38036 Roccastrada (GR) It- } \\
\text { aly }\end{array}$ \\
Silky Rock & IV & $100 / 31$ & 9866 & $\begin{array}{c}\text { Whipmix, Louis Ville, Ken- } \\
\text { tucky, USA }\end{array}$ \\
Geastone & III & $100 / 30$ & 600030605 & $\begin{array}{c}\text { Zeus Seri Loc. Tamburino } \\
\text { 58036 Roccastrada (GR) It- } \\
\text { aly }\end{array}$ \\
Zeta & III & $100 / 31$ & GSG/A 0805 & Industria Zingardi, Italy \\
\hline
\end{tabular}

The overfilled mold was then covered with another glass plate which was rocked into place and pressed firmly into contact to ensure flat and parallel ends. After 20 minutes, the glass plates were removed and the metal mold was dissembled carefully and the stone cylinders were easily separated from the mold. By this method, 80 specimens were prepared and all specimens were coded. Then, all specimens were stored in air at room temperature range of $23+2{ }^{\circ} \mathrm{C}$ for 1 hour ${ }^{(18)}$.

The total 80 specimens were divided into 4 main groups, each group represented on type of stone. For each type of dental stone (each group), 20 specimens were prepared, 10 specimens were left untreated as a control, while the other 10 specimens were microwave irradiated.

The microwave irradiation was performed in a household microwave oven
(Samsung, Type CK, 99s, 2, 450 frequency) at 900 watts for 5 minutes ${ }^{(19)}$. To ensure that the specimens were adequately irradiated on all surfaces, they were first exposed for 2.5 minutes and subsequently turned upside down and irradiated again for the same amount of time. A cup with $200 \mathrm{ml}$ water was placed in the microwave oven to protect the magnetron ${ }^{(20)}$.

The DTS was conducted on a mechanical testing machine (Inc., Model CN 472, EVANSTON Ill, USA) at a cross head speed of $1.0 \mathrm{~mm} /$ minute $^{(18)}$.

An apparatus made of metal was designed and constructed especially for the test (Figure 1). The horizontal metal fracturing section was $6 \mathrm{~cm}$ length, $1 \mathrm{~cm}$ thickness and $4 \mathrm{~cm}$ width. It was mounted at the end of a vertical metal rod $(1 \mathrm{~cm}$ in diameter) which is fixed to the mechanical testing machine ${ }^{(21)}$.

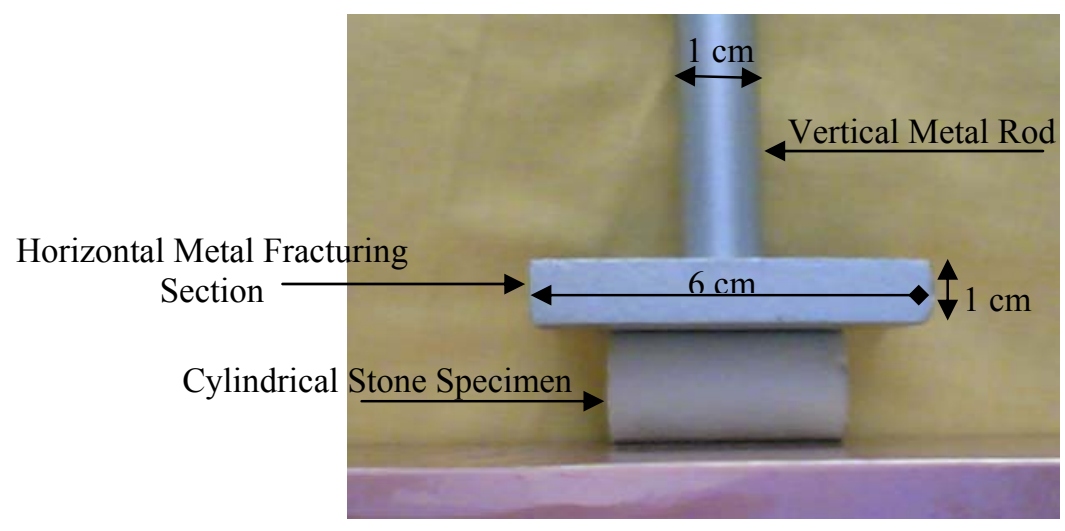

Figure (1): Metal apparatus for diametral tensile strength test 
The cylindrical stone specimen was placed in horizontal position between the table of the testing machine at the bottom and the metal fracturing section and compressed until fracture occurred (Figure 1). The compressive force recorded on the broving ring (scale) at the moment of fracture.

The DTS was then calculated in Megapascal (MPa) using the equation: ${ }^{(18)}$

$$
\mathrm{DTS}=\frac{2 \mathrm{f}}{\pi \mathrm{bd}}
$$

Where: $\mathrm{f}=$ breaking load; $\mathrm{b}=$ specimen height; $d=$ cross-sectional diameter.
The data were statistically analyzed using Student's t-test to compare between the two subgroups: Control and microwave irradiated for each main group then analysis of variance (ANOVA) followed by Duncan's Multiple Range Test to compare between the four types of dental stone.

\section{RESULTS}

The mean and standard deviation of the DTS for each tested group and Student's t-test were calculated and listed in Table (2).

Table (2): Mean, standard deviation and Student's t-test for the diametral tensile strength of the tested groups

\begin{tabular}{|c|c|c|c|c|}
\hline Groups & No. & Mean $(\mathrm{MPa}) \pm$ SD & t-test & Significance \\
\hline \multicolumn{5}{|l|}{ 1. Silky Rock Type IV } \\
\hline Control & 10 & $10.3 \pm 1.111$ & \multirow{2}{*}{-19.93} & 0.000 \\
\hline Microwave Irradiated & 10 & $20.2+1.111$ & & $\mathrm{~S}$ \\
\hline \multicolumn{5}{|l|}{ 2. Micromod Type IV } \\
\hline Control & 10 & $9.93+0.921$ & \multirow{2}{*}{-20.11} & 0.000 \\
\hline Microwave Irradiated & 10 & $19.7 \pm 1.229$ & & $\mathrm{~S}$ \\
\hline \multicolumn{5}{|l|}{ 3. Geastone Type III } \\
\hline Control & 10 & $4.55 \pm 0.685$ & \multirow{2}{*}{-24.47} & 0.000 \\
\hline Microwave Irradiated & 10 & $13.0 \pm 0.850$ & & $\mathrm{~S}$ \\
\hline \multicolumn{5}{|l|}{ 4. Zeta Type III } \\
\hline Control & 10 & $4.85 \pm 0.709$ & \multirow{2}{*}{-26.01} & 0.000 \\
\hline Microwave Irradiated & 10 & $14.2+0.888$ & & $\mathrm{~S}$ \\
\hline
\end{tabular}

S: Significant difference $(p \leq 0.05)$.

In order to evaluate the effect of microwave irradiation (disinfection) on the DTS for each stone type (main group), Student's t-test was performed as shown in Table (2), which revealed that there were significant differences between microwave irradiated group and control group for all types of dental stone, and this revealed that microwave irradiated Silky Rock type IV, microwave irradiated Micromod type IV, microwave irradiated Geastone type III and microwave irradiated Zeta type III were significantly higher than the corresponding control groups, respectively.

For evaluation of the effect of type of dental stone on the DTS, ANOVA (Table 3) showed that there were significant differences between the four types of dental stone.

Table (3): Analysis of variance for the effect of type of dental stone on diametral tensile strength

\begin{tabular}{cccccc}
\hline & $\begin{array}{c}\text { Sum of } \\
\text { Squares }\end{array}$ & df & $\begin{array}{c}\text { Mean } \\
\text { Square }\end{array}$ & F-value & $\boldsymbol{p}$-value \\
\hline Between Groups & 699.593 & 3 & 233.198 & \multirow{2}{*}{9.699} & 0.000 \\
Within Groups & 1827.231 & 76 & 24.043 & & \\
\hline Total & 2526.824 & 79 & & &
\end{tabular}


Duncan's Multiple Range Test (Table 4) showed that Silky Rock type IV $(15.250 \mathrm{MPa})$ and Micromod type IV
$(14.815 \mathrm{MPa})$ were significantly higher than those of Zeta type III $(9.525 \mathrm{MPa})$ and Geastone type III (8.775 MPa).

Table (4): Duncan's Multiple Range test for the effect of type of dental stone on diametral tensile strength

\begin{tabular}{|c|c|c|c|c|}
\hline Group & No. & $\begin{array}{l}\text { Mean } \\
\text { (MPa) }\end{array}$ & \pm SD & $\begin{array}{c}\text { Duncan's } \\
\text { Grouping* }\end{array}$ \\
\hline Silky Rock Type IV & 20 & 15.250 & 5.192 & B \\
\hline Micromod Type IV & 20 & 14.815 & 5.122 & B \\
\hline Geastone Type III & 20 & 8.775 & 4.399 & A \\
\hline Zeta Type III & 20 & 9.525 & 4.859 & A \\
\hline
\end{tabular}

SD: Standard deviation.

*Means with different letters were statistically significant $(p \leq 0.05)$.

\section{DISCUSSION}

The most important results in this study was microwave disinfection of dental stone by household microwave oven cause significantly increase in DTS.

The clinical importance of the cycle that is used in present study (900 watts at $2.450 \mathrm{MHz}$ ) for 5 minutes cause striking reduction of bacteria on the cast as shown in previous study ${ }^{(19)}$.

The most critical factor in using microwave technique for disinfection of dental stones are the power and time of microwave irradiation, although previous investigation ${ }^{(22)}$ showed that high power of microwave irradiation (1,400 watts) and for different time duration has bactericidal effect on different microorganisms. There was some concern that cracks or porosities in the surface might result when gypsum casts were irradiated with high wattage $(1,450$ watts $),{ }^{(23)}$ as rapid water escape from dental stone may be harmful to the material, causing holes and cracks on the outer surface which may lead to fracture during handling.

There are little researches on the strength of gypsum materials disinfected by microwave energy ${ }^{(24,25)}$. So, in this study, an evaluation of one of the most important properties of gypsum products that's disinfected by microwave energy was performed which is tensile strength.

With the materials that exhibit limited plastic deformation, the DTS has been used successfully, ${ }^{(26,27)}$ which is the test in which the compressive load is placed by a flat plate against the side of a short cylin- drical specimen. The vertical compressive force along the side of the specimen produces a tensile stress that is perpendicular to the vertical plane that pass through the center of the specimen. Fracture occurs along this vertical plane, in such situation, the tensile stress is directly proportional to the compressive load applied ${ }^{(27)}$.

For all types of dental stone (Silky Rock type IV, Micromod type IV, Geastone type III and Zeta type III) microwave disinfection cause significant increase in DTS as shown in (Figure 2). Possible scientific explanation for such increase may be related to the fact that the strength of gypsum products is conversely related to free water content in set product ${ }^{(28)}$. The one hour after mixing compressive strength is a measure of wet strength while gypsum may take as long as 7 days to dry, ${ }^{(29)}$ and the dry strength may be two or more time the wet strength ${ }^{(27,28)}$.

Anusavice $^{(27)}$ has recommended that type III dental stone even one hour after mixing, approximately $7 \%$ excess water remains in air-dried gypsum materials, and because type IV dental stone has more gauging water, a longer drying period may be necessary to expel the excess water ${ }^{(21)}$.

So, in addition to kill pathogenic microorganisms, microwave irradiation of gypsum specimens at 900 watts for 5 minutes will remove this free water content and lead to significant increase in DTS in relation to control groups.

Other findings of this study revealed that DTS of type IV dental stone (Micromod 14.815 MPa, Silky Rock 15.25 MPa) were significantly higher than the DTS of 
type III dental stone (Geastone $8.775 \mathrm{MPa}$, Zeta $9.525 \mathrm{MPa}$ ) and these differences in DTS may be due to the fact that dental stone type IV contains an $\alpha$-hemihydrate of the Densite type. Cuboidal shape particles and the reduced surface area produce dental stone with high mechanical properties $^{(28)}$.

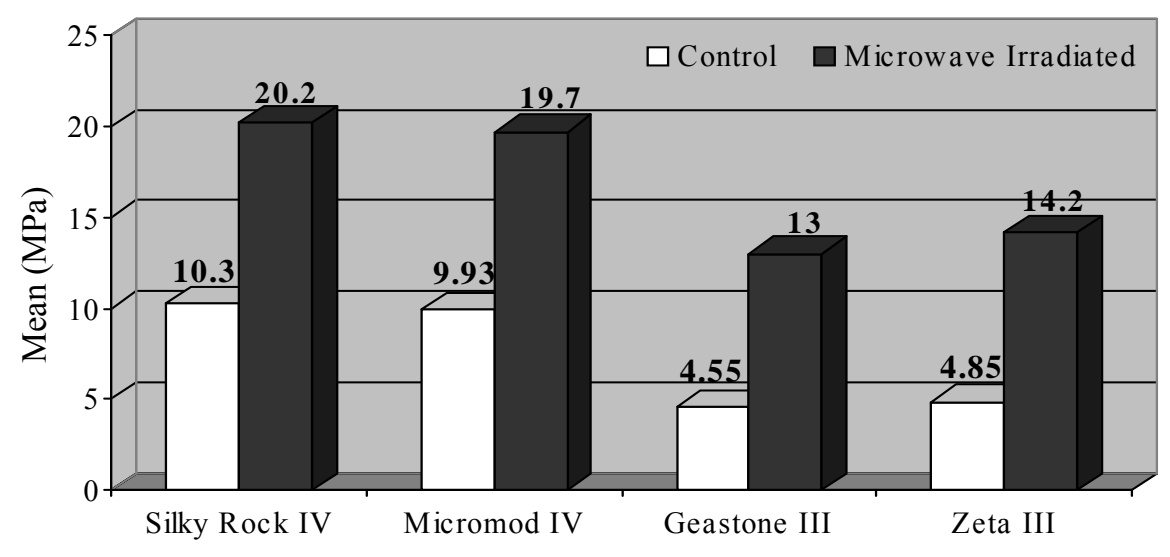

Figure (2): The effect of microwave irradiation on the diametral tensile strength for the four types of dental stone

\section{CONCLUSION}

Microwave disinfection of gypsum cast at 900 watts for 5 minutes cause significantly increase in diametral tensile strength of gypsum products, and this technique could be done safely, quickly with household microwave oven without need of special skills, chemicals or additives.

Microwave disinfected dental stone type IV exhibited more DTS than that of dental stone type III.

\section{REFERENCES}

1. Katberg JWJr. Cross contamination via the prosthodontic laboratory. $J$ Prosthet Dent. 1974; 32: 412-419.

2. Kahn RC, Lancaster MV, Kate WJr. The microbiologic cross-contamination of dental prostheses. J Prosthet Dent. 1982; 47: 556-559.

3. Larato DC. Disinfection of pumice. $J$ Prosthet Dent. 1967; 18: 534-535.

4. ADA Council on Scientific Affairs and ADA Council on Dental Practice. Infection control recommendations for the dental office and the dental laboratory. $J$ Am Dent Assoc. 1996; 127: 672-680.

5. Naylor WP. Infection control in fixed prosthodontics. Dent Clin North Am. 1992; 36: 809-831.
6. Abdelaziz KM, Combe EC, Hodges JS. The effect of disinfectants on the properties of dental gypsum. Part 2: Surfaces properties. J Prosthodont. 2002; 11: 234 240.

7. Stern MA, Johnson GH, Toolson LB. An evaluation of dental stones after repeated exposure to spray disinfectant. Part I: Abrasion and compressive strength. $J$ Prosthet Dent. 1991; 65: 713-718.

8. Sarma AC, Neiman R. A study on the effect of disinfectant chemicals on physical properties of die stone. Quintessence Int. 1990; 21: 53-59.

9. DePaola LG, Minah GE, Elias SA. Growth and potential pathogens in denture soaking solution of myelosuppressed cancer patients. J Prosthet Dent. 1984; 51: 554-558.

10. Tebrock OC, Englemeire RL, Mayfield TG, Adams HY. Managing dental impressions and casts of patients with communicable disease. Gen Dent. 1989; 37: 490-495.

11. Bass RA, Plummer KO, Anderson EF. The effect of surface disinfectant on a dental cast. J Prosthet Dent. 1992; 67: 723-725.

12. Ivanovski S, Savage NW, Brockhurst PJ, Bird PS. Disinfection of dental stone casts: Antimicrobial effects and physical property alterations. Dent Mater. 1995; 
11: 19-23.

13. White MP, Brockhurst PJ. The effect of steam sterilization on the properties of set dental gypsum models. Aust Dent $J$. 1996; 41: 128-133.

14. Schutt RW. Bactericidal effect of a disinfected dental stone on irreversible hydrocolloid impressions and stone casts. J Prosthet Dent. 1989; 62: 605-607.

15. Davis BA, Powers SM. Effect of immersion disinfection on properties of impression materials. J Prosthodont. 1994; 3: 31-34.

16. Holtan JR, Olin PS, Rudney JD. Dimensional stability of polyvinyl-siloxane impression materials following ethylene oxide and steam autoclave sterilization. $J$ Prosthet Dent. 1991; 65: 519-525.

17. American National Standards. American Dental Association Specification No. 25 for Dental Gypsum Products. New York. American National Standards Institute. 2000; Pp: 244-253.

18. Abdelaziz KM, Combe ECF, Hodges JS. The effect of disinfectants on the properties of dental gypsum. Part 1: Mechanical properties. J Prosthodont. 2002; 11: 161167.

19. Berg E, Nils Skavg ØN. High-level microwave disinfection of dental gypsum casts. Int J Prosthodont. 2005; 18: 520525.

20. Schwedhelm ER, Lepe X. Fracture strength of type IV and type V die stone as a function of time. $J$ Prosthet Dent. 1997; 78: 554-559.
21. Hersek N, Canay S, Akca K, Ciftci Y. Tensile strength of type IV dental stones dried in a microwave oven. $J$ Prosthet Dent. 2002; 87: 499-502.

22. Nadjowski L, Drugas AZ, Kotnik V. The killing activity of microwaves on some non-sporogenic and sporogenic medically important bacterial strains. $J$ Hosp Infect. 1991; 19: 239-247.

23. Luebke RJ, Chan KC. Effect of microwave oven drying on surface hardness of dental gypsum products. $J$ Prosthet Dent. 1985; 54: 431-435.

24. Tuncer N, Tüfekcioglu HB, Calikkocaoglu S. Investigation on the compressive strength of several gypsum products dried by microwave oven with different programs. J Prosthet Dent. 1993; 69: 333-339.

25. Luebke RJ, Schneider RL. Microwave oven drying of artificial stone. $J$ Prosthet Dent. 1985; 53: 261-265.

26. Tay WM, Braden M. Load deformation behaviour during a diametric test. Biomater. 1990; 11: 361-366.

27. Anusavice KJ. Phillip's Science of Dental Materials. $10^{\text {th }}$ ed. WB Saunders Co. Philadelphia. 1996; Pp: 62, 189, 191, 203.

28. Craig RG. Restorative Dental Materials. $10^{\text {th }}$ ed. CV Mosby Co. St Louis. 1997; Pp: 200-204.

29. Kaiser DA. A study of distortion and surface hardness of improved artificial stone casts. J Prosthet Dent. 1976; 36: 373-380. 